Pak. j. sci. ind. res. Ser. B: biol. sci. 2021 64B(2) 160-166

\title{
Characterization of Maize Hybrids (Zea mays L.) for Salt Tolerance at Seedling Stage
}

\author{
Muhammad Ali ${ }^{a *}$, Ghulam Hassan Abbasi ${ }^{a}$, Moazzam Jamil ${ }^{a}$, Muhammad Aown Sammar Razab \\ and Salman Ahmad \\ a Department of Soil Science, University College of Agriculture and Environmental Sciences, The Islamia University \\ of Bahawalpur, 63100, Pakistan \\ ${ }^{b}$ Department of Agronomy, University College of Agriculture and Environmental Sciences, The Islamia University \\ of Bahawalpur, 63100, Pakistan
}

(received September 5, 2018; revised January 14, 2019; accepted January 10, 2019)

\begin{abstract}
Salinity is the most atrocious environmental aspects restricting the productivity of agricultural crops. To fulfill global increasing demand of food, selection of salt tolerant genotypes to get production from salt affected soils is imperative. In the present experiment, ten maize genotypes were evaluated against four salinity levels (control, $40 \mathrm{mM}, 80 \mathrm{mM}$ and $120 \mathrm{mM} \mathrm{NaCl}$ ) using different agronomic and physiological criteria. Significant variations were observed in all morpho-physiological and ionic attributes in all maize hybrids. Results depicts that maize hybrid 2225 exhibited salt tolerance and show higher plant biomass, chlorophyll and water contents, membrane stability along with $\mathrm{K}^{+} / \mathrm{Na}^{+}$ratio. While maize hybrid 8711 had lower plant growth among all maize hybrids and considered as salt sensitive genotype. The results can be used as a selection tool for salinity tolerance in maize and provide a better source for breeders for further assessment on saline lands.
\end{abstract}

Keywords: maize, RWC, MSI, K/Na ratio

\section{Introduction}

Soil salinity is a serious problem and is increasing steadily in many parts of the world, in particular in arid and semi-arid areas (Zhu et al., 2017). Salinization is spreading more rapidly in irrigated lands because of inappropriate management of irrigation and drainage. Saline soils occupy $7 \%$ of the earth's land surface and increased salinization of arable land will result into $50 \%$ land loss by the middle of the 21 st century (Ahanger et al., 2017). Under salt stress, important processes such as lipid metabolism, protein synthesis and photosynthetic capacity are distorted subsequently results in poor seed germination and plant growth (Abraha and Yohannes, 2013). Salt stress deteriorate chlorophyll contents, nitrate contents, inhibit carbonic anhydrase, nitrate reductase, net phtotosynthetic rate, stomatal conductance, PSII reaction centre, disrupt electron transport in the photosynthetic apparatus, induced ion imbalance along with disturbed membrane integrity and water relations (Flowers and Colmer, 2015).

Various factors can influence plant responses to salinity stress such as plant genotype, duration of stress, physiological process of growth, activity of photo-

*Author for correspondence;

E-mail: seadiamond61@yahoo.com synthesis machinery, metabolic pathways (Gupta and Wang, 2014). Salt tolerance is a complex phenomenon and plants exhibit a different adaptations at sub-cellular, cellular and organ levels such as regulating hormonal and osmotic balance along with activation of the antioxidant defense system to cope with salinity (Yasmeen et al., 2013) and enhancing salt tolerance in crops also minimize the reclamation costs of saline land (Scudiero et al., 2016).

Maize (Zea mays L.) is cultivated on more than 142 million/ha ha of land and it is estimated to produce around 913 million tons of grain (one third of the total global grain production), but this crop is normally sensitive to salt stress (Katerji et al., 2013). Due to its cross pollinated nature, maize is a highly polymorphic crop in which salt resistance exhibit (Medici et al., 2007). Characterization of maize hybrids against salt resistance on the basis of some morpho-physiological attributes during early growth stages are often find valuable (Kusvuran et al., 2015). Maize is moderately salt-susceptible but some tolerant genotypes may exist with more potential to exclude $\mathrm{Na}^{+}$and $\mathrm{Cl}^{-}$from leaf sap to maintain higher $\mathrm{K}^{+} / \mathrm{Na}^{+}$ratios (Kaya et al., 2015).

Taking into account all stated facts, present study was conducted using ten maize hybrids against four salt concentrations (control, 40, 80 and $120 \mathrm{mM} \mathrm{NaCl}$ ) with 
an aim to evaluate the deleterious effects of salinity on plant morpho-physiological and ionic attributes and to identify premier salt tolerant maize hybrid that could further be utilized to achieve maximum yield from salt affected soils.

\section{Material and Methods}

Experimental site and growth conditions. A hydroponic experiment was conducted in warehouse (experimental area covered with steel fence to provide protection from birds and other disturbance) at The Islamia University of Bahawalpur, Pakistan. The seeds of ten maize hybrids $(2225,360,1574,1548,6145$, $6142,8441,8711$, hycorn 11 and 670) were collected from well known facts Monsanto, ICI, Syngenta, FMC and Pioneer. Sterilized seeds were sown in moist sand culture. Nursery was raised in ambient sun light and moisture (field capacity). At two leaf stage, uniform seedlings were transferred into the styrofoam sheet floating on water in iron tub of $200 \mathrm{~L}$ capacity. Plants were provided complete nutrition by using half strength Hogland solution (Hogland and Arnon, 1950). NaCl was used to develop four salt levels (control, 40, 80 and $120 \mathrm{mM} \mathrm{NaCl}$ ). The experiment was performed in Complete Randomize Design (CRD) with five replicates having split plot arrangement. The $\mathrm{pH}$ of solution was calibrated regularly and maintained at $6.5 \pm 0.5$ and bubbling air was given by using aeration pumps. Growth, physiological and ionic parameters were taken after four weeks of stress.

Plant harvesting and analysis. Plants were harvested after four weeks of stress and growth parameters along with other physiological, photosynthetic and ionic attributes were measured by following standard procedures.

Physiological attributes. Fully expended youngest leaf of plants from each treatment was selected and after taking fresh weight (FW), leaves were soaked in distilled water to get turgid weight (TW). Dry weight was obtained by placing these leaves in oven for $72 \mathrm{~h}$ at 65 ${ }^{\circ} \mathrm{C}$ (Lazcano-Ferrat and Lovatt, 1999)

RWC $(\%)=(F W-D W) /(T W-D W) \times 100$

Leaf disc (100 mg) were thoroughly washed and heated in distilled water at $30{ }^{\circ} \mathrm{C}$ for $30 \mathrm{~min}$ and electrical conductivity $\left(\mathrm{C}_{1}\right)$ was recorded. Same sample were placed at $100{ }^{\circ} \mathrm{C}$ for $10 \mathrm{~min}$ and electrical conductivity $\left(\mathrm{C}_{2}\right)$ was noted. (Sairam and Saxena, 2000).

$\operatorname{MSI}(\%)=\left[1-\left(\mathrm{C}_{1} / \mathrm{C}_{2}\right)\right] \times 100$
Chlorophyll content. Leaf material (0.05 g) was extracted in $10 \mathrm{ml}$ dimethylsulfoxide and heated at 65 ${ }^{\circ} \mathrm{C}$ for $4 \mathrm{~h}$. Absorbance of extract was recorded at 660 $\mathrm{nm}$ and $665 \mathrm{~nm}$ for chlorophyll $\mathrm{a}$ and $\mathrm{b}$ with spectrophotometer according to the method of (Wellburn, 1994).

Ionic attributes. Potassium and sodium concentration were determined by taking dried ground shoot material (0.01 g) digested with hydrogen peroxide and sulphuric acid at $350{ }^{\circ} \mathrm{C}$ for $30 \mathrm{~min}$ and digested material was colorless according to the method of Wolf (1982) by using flame photometer (Jenway, PFP-7).

Statistical analysis. All values reported in this experiment are mean of 5 replicates. The data were analyzed by using Statistics, version 8.1 by applying complete randomized design with factorial arrangement.

\section{Results and Discussion}

The analyzed data regarding root and shoot length (Table 1) revealed that salt stress exerted impregnable negative impacts on root and shoot length of all maize hybrids. However, the impact of salinity influence significantly among maize hybrids. Minimum salt effect was noted in maize hybrids 2225 where 90,73 and 54\% growth in root length and 83, 65 and 53\% shoot length at low, medium and high salt stress was observed when compared with control. While, maize hybrid 8711 show increased sensitivity to $\mathrm{NaCl}$ application and show minimum values (on an average less than $50 \%$ ) of root and shoot length respectively.

Application of $\mathrm{NaCl}$ severely affected plant biomass and result in decrease of fresh and dry biomass of plants. Among all hybrids, least reduction in fresh biomass (Table 2) was manifested by maize hybrid 2225, however, at high salt concentration (80 and $120 \mathrm{mM}$ $\mathrm{NaCl}$ ) reduction was up to 70 and $51 \%$ in root, while 68 and 54\% in shoot fresh weight relative to control. At $120 \mathrm{mM} \mathrm{NaCl}$, maize hybrid 8711 proved to be high salt susceptible and shoot and root fresh biomass was decreased up to 38 and 34\%. Maize hybrid 1574 effectively grows at high salt level $(120 \mathrm{mM})$ and present more than 50\% reduction in root and shoot fresh weight. All maize hybrids follow a similar trend in case of root and shoot dry weight (Table 3 ) as in case of fresh weight. Maximum reduction was noted in maize hybrid 8711 where level of decline was 33 and $30 \%$ at $120 \mathrm{mM}$ $\mathrm{NaCl}$, while minimum reductions 54 and $43 \%$ was observed in maize hybrid 2225 at same level of salt stress. 
Table 1. Effect of salt stress on root length and shoot length of ten maize hybrids. Values depicts the mean of five replicates and figures not sharing the same letter in each column differ significantly at 0.05 probability level.

\begin{tabular}{|c|c|c|c|c|c|c|c|c|c|c|}
\hline \multirow{2}{*}{$\begin{array}{l}\text { Maize } \\
\text { hybrids }\end{array}$} & \multicolumn{5}{|c|}{ Root length $(\mathrm{cm})$} & \multicolumn{5}{|c|}{ Shoot length $(\mathrm{cm})$} \\
\hline & Control & $40 \mathrm{mM}$ & $80 \mathrm{mM}$ & $120 \mathrm{mM}$ & Mean & Control & $40 \mathrm{mM}$ & $80 \mathrm{mM}$ & $120 \mathrm{mM}$ & Mean \\
\hline 2225 & $48.60^{\mathrm{a}}$ & $44.36^{\mathrm{c}}$ & $36.3^{\mathrm{k}}$ & $26.08^{\circ}$ & $38.83^{\mathrm{a}}$ & $117.38^{\mathrm{a}}$ & $98.26^{\mathrm{g}}$ & $79.40^{1}$ & $61.54^{\mathrm{r}}$ & $89.14^{\mathrm{a}}$ \\
\hline 360 & $44.32^{\mathrm{c}}$ & $40.52^{\text {ef }}$ & $30.68^{n}$ & $22.22^{\mathrm{r}}$ & $34.43^{\mathrm{c}}$ & $109.88^{c}$ & $89.90^{\mathrm{k}}$ & $73.58^{\mathrm{op}}$ & $56.60^{\mathrm{u}}$ & $82.49^{\text {de }}$ \\
\hline 1574 & $46.28^{\mathrm{b}}$ & $41.28^{\mathrm{e}}$ & $34.18^{1}$ & $23.52^{\mathrm{p}}$ & $36.31^{\mathrm{b}}$ & $116^{\mathrm{b}}$ & $96.24^{\mathrm{h}}$ & $78.38^{\mathrm{m}}$ & $60.82^{\mathrm{rs}}$ & $87.86^{\mathrm{b}}$ \\
\hline 1548 & $41.16^{\mathrm{e}}$ & $37.52^{\mathrm{ij}}$ & $31.08^{\mathrm{n}}$ & $20.84^{\mathrm{s}}$ & $32.65^{\mathrm{e}}$ & $107.16^{\mathrm{e}}$ & $92.32^{\mathrm{ij}}$ & $74.60^{\mathrm{n}}$ & $57.72^{\mathrm{t}}$ & $82.95^{\mathrm{cd}}$ \\
\hline 6145 & $42.84^{\mathrm{d}}$ & $39.12^{\text {gh }}$ & $32.80^{\mathrm{m}}$ & $22.26^{\mathrm{qr}}$ & $34.25^{\mathrm{cd}}$ & $107.56^{\mathrm{e}}$ & $93.16^{\mathrm{i}}$ & $75.04^{\mathrm{n}}$ & $57.60^{\mathrm{t}}$ & $83.34^{\mathrm{c}}$ \\
\hline 6142 & $43.46^{\mathrm{cd}}$ & $39.74^{\mathrm{fg}}$ & $33.62^{\mathrm{lm}}$ & $21.42^{\mathrm{rs}}$ & $34.56^{\mathrm{c}}$ & $108.66^{\mathrm{d}}$ & $89.12^{\mathrm{k}}$ & $72.22^{\mathrm{q}}$ & $56.08^{\mathrm{u}}$ & $81.52^{\mathrm{f}}$ \\
\hline 8441 & $38.24^{\mathrm{hi}}$ & $36.20^{\mathrm{k}}$ & $25.42^{\circ}$ & $18.36^{\mathrm{t}}$ & $29.55^{\mathrm{f}}$ & $102.40^{\mathrm{f}}$ & $78.34^{\mathrm{m}}$ & $61.42^{\mathrm{rs}}$ & $51.10^{\mathrm{w}}$ & $73.31^{\mathrm{g}}$ \\
\hline 8711 & $36.22^{\mathrm{k}}$ & $32.58^{\mathrm{m}}$ & $23.28^{\mathrm{pq}}$ & $17.76^{\mathrm{t}}$ & $27.46^{\mathrm{g}}$ & $101.86^{\mathrm{f}}$ & $77.74^{\mathrm{m}}$ & $60.48^{s}$ & $50.60^{\mathrm{w}}$ & $72.67^{\mathrm{h}}$ \\
\hline Hycorn 11 & $40.78^{\text {ef }}$ & $36.68^{\mathrm{jk}}$ & $30.40^{\mathrm{n}}$ & $21.62^{\mathrm{rs}}$ & $32.37^{\mathrm{e}}$ & $106.76^{\mathrm{e}}$ & $91.64^{\mathrm{j}}$ & $73.04^{\mathrm{pq}}$ & $55.00^{\mathrm{v}}$ & $81.61^{\mathrm{f}}$ \\
\hline 607 & $43.88^{\mathrm{cd}}$ & $39.14^{\text {gh }}$ & $30.54^{\mathrm{n}}$ & $21.65^{\mathrm{rs}}$ & $33.80^{\mathrm{d}}$ & $107.04^{\mathrm{e}}$ & $92.12^{\mathrm{j}}$ & $74.38^{\text {no }}$ & $56.10^{\mathrm{u}}$ & $82.41^{\mathrm{e}}$ \\
\hline
\end{tabular}

Table 2. Effect of salt stress on root fresh weight and shoot fresh weight of ten maize hybrids. Values depicts the mean of five replicates and figures not sharing the same letter in each column differ significantly at 0.05 probability level.

\begin{tabular}{|c|c|c|c|c|c|c|c|c|c|c|}
\hline \multirow{2}{*}{$\begin{array}{l}\text { Maize } \\
\text { hybrids }\end{array}$} & \multicolumn{5}{|c|}{ Root fresh weight (g) } & \multicolumn{5}{|c|}{ Shoot fresh weight (g) } \\
\hline & Control & $40 \mathrm{mM}$ & $80 \mathrm{mM}$ & $120 \mathrm{mM}$ & Mean & Control & $40 \mathrm{mM}$ & $80 \mathrm{mM}$ & $120 \mathrm{mM}$ & Mean \\
\hline 2225 & $11.22^{\mathrm{a}}$ & $10.16^{\mathrm{c}}$ & $8.64^{\mathrm{i}}$ & $5.74^{r}$ & $8.94^{\mathrm{a}}$ & $56.64^{\mathrm{a}}$ & $44.48^{f}$ & $37.62^{\mathrm{m}}$ & $29.48^{t}$ & $42.05^{\mathrm{a}}$ \\
\hline 360 & $9.54^{\mathrm{ef}}$ & $9.00^{\mathrm{gh}}$ & $7.24^{\mathrm{mn}}$ & $4.54^{t}$ & $7.58^{\mathrm{c}}$ & $51.50^{\mathrm{c}}$ & $40.46^{\mathrm{jk}}$ & $33.60^{\circ}$ & $24.36^{\mathrm{x}}$ & $37.48^{c}$ \\
\hline 1574 & $10.62^{\mathrm{b}}$ & $9.82^{\mathrm{de}}$ & $8.20^{\mathrm{jk}}$ & $5.56^{\mathrm{rs}}$ & $8.55^{\mathrm{b}}$ & $55.66^{\mathrm{b}}$ & $43.54^{\mathrm{g}}$ & $36.78^{n}$ & $28.56^{\mathrm{u}}$ & $41.13^{b}$ \\
\hline 1548 & $10.00^{\mathrm{cd}}$ & $8.42^{\mathrm{ij}}$ & $6.44^{q}$ & $3.80^{\mathrm{u}}$ & $7.16^{\mathrm{d}}$ & $47.14^{\mathrm{e}}$ & $39.22^{1}$ & $32.34^{\mathrm{q}}$ & $23.68^{z}$ & $35.59^{\mathrm{g}}$ \\
\hline 6145 & $9.24^{\mathrm{fg}}$ & $8.10^{\mathrm{k}}$ & $6.84^{\mathrm{op}}$ & $4.06^{\mathrm{u}}$ & $7.06^{\mathrm{d}}$ & $50.44^{\mathrm{d}}$ & $40.22^{\mathrm{k}}$ & $33.28^{\circ}$ & $24.52^{x}$ & $37.11^{\mathrm{ef}}$ \\
\hline 6142 & $8.72^{\text {hi }}$ & $7.62^{1}$ & $6.62^{\mathrm{pq}}$ & $3.86^{\mathrm{u}}$ & $6.70^{\mathrm{e}}$ & $51.56^{\mathrm{c}}$ & $40.70^{j}$ & $32.84^{\mathrm{p}}$ & $23.84^{y z}$ & $37.24^{\mathrm{de}}$ \\
\hline 8441 & $8.08^{\mathrm{k}}$ & $6.82^{\text {op }}$ & $5.72^{\mathrm{r}}$ & $2.80^{\mathrm{v}}$ & $5.85^{\mathrm{f}}$ & $43.78^{\mathrm{g}}$ & $31.66^{\mathrm{r}}$ & $26.22^{\mathrm{v}}$ & $19.24^{z}$ & $30.22^{\mathrm{h}}$ \\
\hline 8711 & $8.02^{\mathrm{k}}$ & $6.44^{\mathrm{q}}$ & $5.36^{\mathrm{s}}$ & $2.34^{\mathrm{w}}$ & $5.54^{\mathrm{g}}$ & $42.40^{\mathrm{h}}$ & $30.70^{\mathrm{s}}$ & $25.74^{\mathrm{w}}$ & $18.00^{\mathrm{z}}$ & $29.21^{\mathrm{i}}$ \\
\hline Hycorn 11 & $10.18^{\mathrm{c}}$ & $9.00^{\mathrm{gh}}$ & $7.06^{\text {no }}$ & $4.56^{\mathrm{t}}$ & $7.7^{\mathrm{c}}$ & $50.38^{\mathrm{d}}$ & $40.42^{\mathrm{jk}}$ & $33.48^{\circ}$ & $23.84^{y z}$ & $37.03^{f}$ \\
\hline 607 & $9.80^{\mathrm{de}}$ & $8.56^{\mathrm{i}}$ & $7.44^{\mathrm{lm}}$ & $4.54^{\mathrm{t}}$ & $7.58^{\mathrm{c}}$ & $50.48^{\mathrm{d}}$ & $31.32^{\mathrm{i}}$ & $33.66^{\circ}$ & $24.14^{x y}$ & $37.40^{\mathrm{cd}}$ \\
\hline
\end{tabular}

Elevated salt application proved deleterious for chlorophyll content in all maize hybrids. At $40 \mathrm{mM}$ concentration, no clear effect of salt stress was noted but under elevated salt level ( 80 and $120 \mathrm{mM})$, chlorophyll content were remarkably declined (Fig. 1). Minimum reduction (32\%) in chlorophyll content were exhibited by maize hybrid 2225, while maize hybrid 8711 proved to be most sensitive (44\% reduction) at high level of salinity and show maximum reduction, while all other eight maize hybrids show reduced values in between these two maize hybrids.

Effect of salinity on MSI and RWC are displayed in Fig. 2 and Fig. 3. Compared to control, $\mathrm{NaCl}$ addition cause remarkable reduction in membrane stability and water relations in all maize hybrids. The highest reduction in membrane stability and water content was noticed in maize hybrid 8711 under all salinity levels with maximum reduction 44 and $41 \%$ at $120 \mathrm{mM}$ followed by maize hybrid 8441 (40 and 37\% respectively), while minimum reduction was expressed by maize hybrid 2225 (33 and 32\%) relative to control at high level of salinity.

Increased salt level in growth medium caused pronounced increase in $\mathrm{Na}+$ concentration (Fig. 4), while reduced $\mathrm{K}^{+}$concentration in all maize hybrids reported in this study (Fig. 5). Under all level of salinization, elevated $\mathrm{Na}^{+}$values was noted in hybrid 8711 followed by hybrid 8441 , while lowest $\mathrm{Na}^{+}$value was remarked in maize hybrid 2225 . The trend in case of $\mathrm{K}^{+}$uptake was opposite by exhibiting least $\mathrm{K}^{+}$uptake with increasing salt level the maximum $\mathrm{K}^{+}$concentration was observed at control in all hybrids. Maize hybrid 2225 proved efficient in keeping maximum $\mathrm{K}^{+}$ concentration under all levels of salt stress. Lessen uptake of $\mathrm{K}^{+}$with increased salinization results in poor of $\mathrm{K}^{+} / \mathrm{Na}^{+}$ratio (Fig. 6) and $70 \%$ decreased in $\mathrm{K}^{+} / \mathrm{Na}^{+}$ was reported in maize hybrid $8711 @ 120 \mathrm{mM} \mathrm{NaCl}$. The maximum $\mathrm{K}^{+}$retaining capacity under high salt 
Table 3. Effect of salt stress on root dry weight and shoot dry weight of ten maize hybrids. Values depicts the mean of five replicates and figures not sharing the same letter in each column differ significantly at 0.05 probability level.

\begin{tabular}{|c|c|c|c|c|c|c|c|c|c|c|}
\hline \multirow{2}{*}{$\begin{array}{l}\text { Maize } \\
\text { hybrids }\end{array}$} & \multicolumn{5}{|c|}{ Root fresh weight (g) } & \multicolumn{5}{|c|}{ Shoot fresh weight (g) } \\
\hline & Control & $40 \mathrm{mM}$ & $80 \mathrm{mM}$ & $120 \mathrm{mM}$ & Mean & Control & $40 \mathrm{mM}$ & $80 \mathrm{mM}$ & $120 \mathrm{mM}$ & Mean \\
\hline 2225 & $3.11^{\mathrm{a}}$ & $2.46^{\mathrm{fg}}$ & $2.10^{\mathrm{jk}}$ & $1.51^{\circ}$ & $2.29^{\mathrm{a}}$ & $10.62^{\mathrm{a}}$ & $7.24^{\mathrm{d}}$ & $6.64^{\mathrm{e}}$ & $4.66^{\mathrm{lmn}}$ & $7.29^{\mathrm{a}}$ \\
\hline 360 & $2.64^{\mathrm{cd}}$ & $2.17^{\mathrm{ij}}$ & $1.93^{1}$ & $1.33^{\mathrm{p}}$ & $2.01^{\mathrm{cd}}$ & $7.68^{\mathrm{d}}$ & $5.44^{\text {ghi }}$ & $5.00^{\mathrm{ijk} l}$ & $3.20^{\mathrm{rs}}$ & $5.33^{\mathrm{d}}$ \\
\hline 1574 & $2.90^{\mathrm{b}}$ & $2.36^{\mathrm{h}}$ & $2.02^{\mathrm{k}}$ & $1.44^{\circ}$ & $2.18^{\mathrm{b}}$ & $8.88^{b}$ & $6.68^{\mathrm{e}}$ & $6.26^{\mathrm{ef}}$ & $4.12^{\mathrm{op}}$ & $6.48^{b}$ \\
\hline 1548 & $2.71^{\mathrm{c}}$ & $2.13^{\mathrm{ij}}$ & $1.93^{1}$ & $1.43^{\circ}$ & $2.05^{\mathrm{c}}$ & $8.28^{\mathrm{c}}$ & $6.06^{\mathrm{f}}$ & $5.40^{\mathrm{hij}}$ & $3.38^{\mathrm{qr}}$ & $5.78^{\mathrm{c}}$ \\
\hline 6145 & $2.52^{\mathrm{ef}}$ & $2.09^{\mathrm{jk}}$ & $1.82^{\mathrm{m}}$ & $1.22^{\mathrm{q}}$ & $1.91^{\mathrm{e}}$ & $7.52^{\mathrm{d}}$ & $5.16^{\mathrm{hijk}}$ & $4.70^{\mathrm{klmn}}$ & $3.04^{\mathrm{rs}}$ & $5.10^{\mathrm{de}}$ \\
\hline 6142 & $2.42^{\mathrm{gh}}$ & $2.03^{\mathrm{k}}$ & $1.81^{\mathrm{m}}$ & $1.13^{\mathrm{r}}$ & $1.85^{\mathrm{f}}$ & $7.22^{\mathrm{d}}$ & $4.92^{\mathrm{jklm}}$ & $4.56^{\mathrm{Imno}}$ & $3.06^{\mathrm{rs}}$ & $4.94^{\mathrm{e}}$ \\
\hline 8441 & $2.19^{\mathrm{i}}$ & $1.72^{\mathrm{n}}$ & $1.30^{\mathrm{pq}}$ & $0.72^{\mathrm{s}}$ & $1.48^{\mathrm{g}}$ & $6.08^{f}$ & $4.80^{\mathrm{klm}}$ & $3.74^{\mathrm{pq}}$ & $1.88^{\mathrm{t}}$ & $4.12^{f}$ \\
\hline 8711 & $2.03^{\mathrm{k}}$ & $1.68^{n}$ & $1.24^{\mathrm{q}}$ & $0.68^{\mathrm{s}}$ & $1.40^{\mathrm{h}}$ & $5.92^{\mathrm{fg}}$ & $4.30^{\text {no }}$ & $3.24^{\mathrm{rs}}$ & $1.72^{t}$ & $3.79^{\mathrm{g}}$ \\
\hline Hycorn 11 & $2.60^{\mathrm{de}}$ & $2.16^{\mathrm{ij}}$ & $1.91^{1}$ & $1.32^{\mathrm{p}}$ & $2.00^{\mathrm{d}}$ & $7.54^{\mathrm{d}}$ & $5.48^{\text {ghi }}$ & $4.52^{\operatorname{lmno}}$ & $2.88^{\mathrm{s}}$ & $5.12^{\mathrm{de}}$ \\
\hline 607 & $2.69^{c}$ & $2.18^{\mathrm{i}}$ & $1.86^{\mathrm{lm}}$ & $1.33^{\mathrm{p}}$ & $2.02^{\mathrm{cd}}$ & $7.62^{d}$ & $5.50^{\mathrm{gh}}$ & $4.50^{\mathrm{mno}}$ & $3.04^{\mathrm{rs}}$ & $5.14^{\mathrm{de}}$ \\
\hline
\end{tabular}

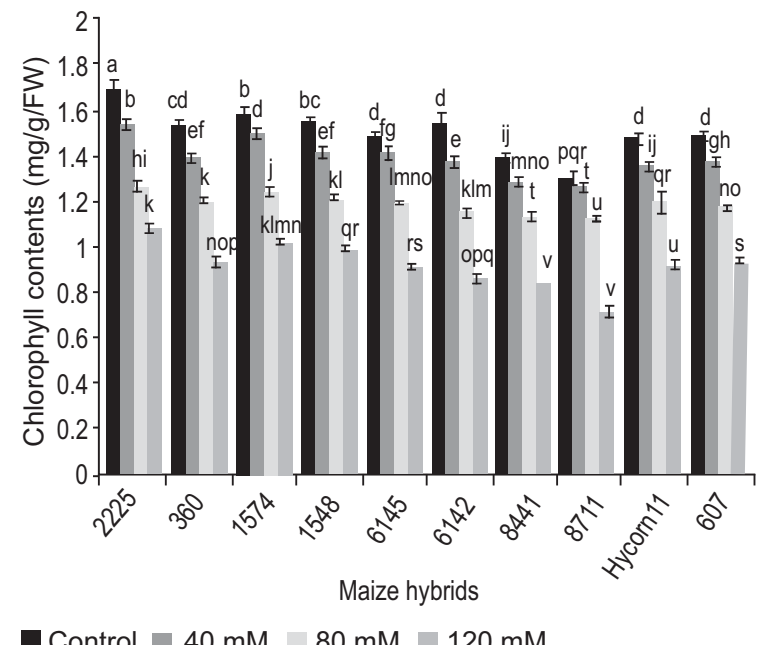

Fig. 1. Effect of salt stress on chlorophyll contents of ten maize hybrids. The bars in the graph show the mean values of five replicates and the error bars are the standard deviations.

stress $(120 \mathrm{mM} \mathrm{NaCl})$ resulted in superior $\mathrm{K}^{+} / \mathrm{Na}^{+}$ratio in maize hybrid 2225, showing better growth under saline condition.

Results reveals that distinction exists among different maize genotypes for salt tolerance but exposure to salinity significantly reduced their growth by interrupting plant morpho-physiological and ionic attributes. Reduction in root length, fresh and dry weight might be due to higher accumulation of $\mathrm{Na}^{+}$and $\mathrm{Cl}^{-}$in the growth medium degraded membrane permeability and causes accumulation of toxic ions at tissue level could

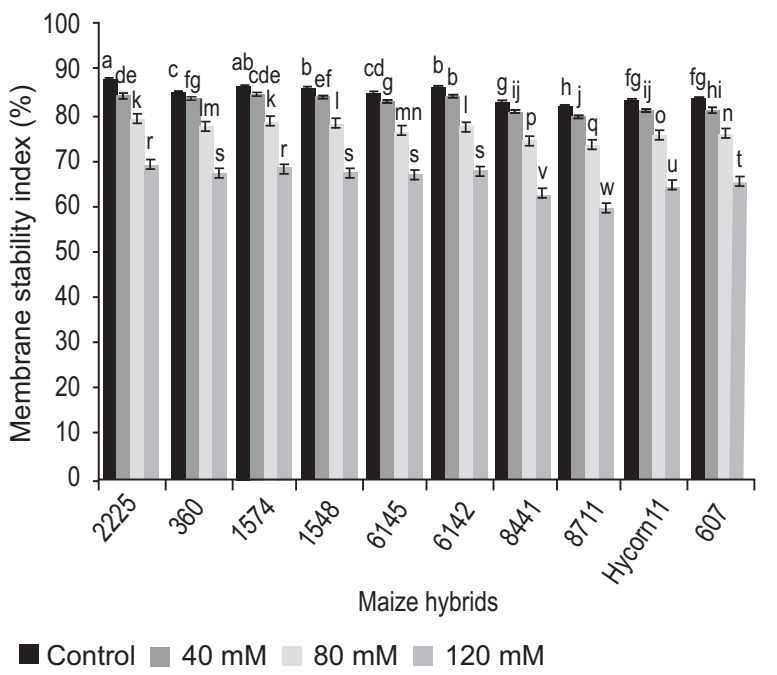

Fig. 2. Effect of salt stress on membrane stability index (MSI) of ten maize hybrids. The bars in the graph show the mean values of five replicates and the error bars are the standard deviations.

be due to imbalance nutrient uptake, suspending the cell division and injuring hypocotyls (Abbasi et al., 2015). Reduction in plant height, fresh and dry biomass is mainly due to subsequent inferior root growth and poor nutrients and transport to aerial parts results in reduced size and number of leaves and osmotic stress produced by high salt accumulation (Zhang et al., 2016). High salt stress effected plant photosynthetic activities and resulting in production of reactive oxygen species (ROS) which significantly reduced plant biomass (Thapar et al., 2008). 


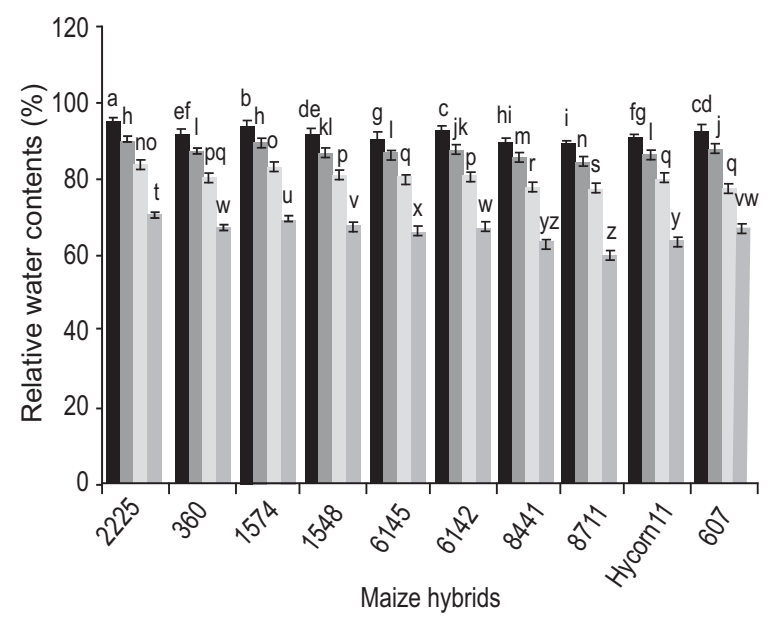

- Control $\square 40 \mathrm{mM} \square 80 \mathrm{mM} \square 120 \mathrm{mM}$

Fig. 3. Effect of salt stress on relative water contents (RWC) of ten maize hybrids. The bars in the graph show the mean values of five replicates and the error bars are the standard deviations.

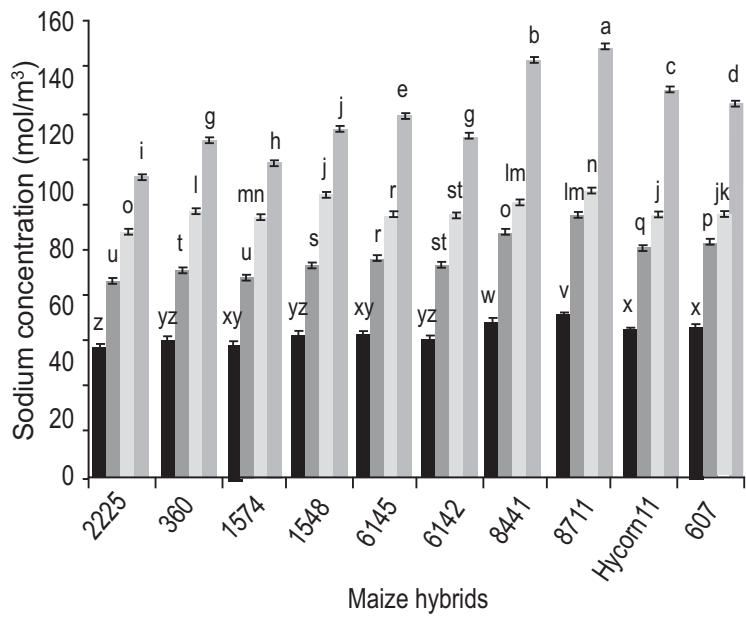

Control $\square 40 \mathrm{mM} \square 80 \mathrm{mM} \square 120 \mathrm{mM}$

Fig. 5. Effect of salt stress on sodium concentration in leaf sap of ten maize hybrids. The bars in the graph show the mean values of five replicates and the error bars are the standard deviations.

Salt application drastically reduced the RWC and MSI in current experiment in all maize hybrids and this reduction was more pronounced in maize hybrid 8711 while least in maize hybrid 2225 . When plant takes excessive $\mathrm{Na}^{+}$, it affects every aspect of plants physiology by disturbing stomatal regulation, transpiration and photosynthetic capacity (Ayoughi et al., 2011). The

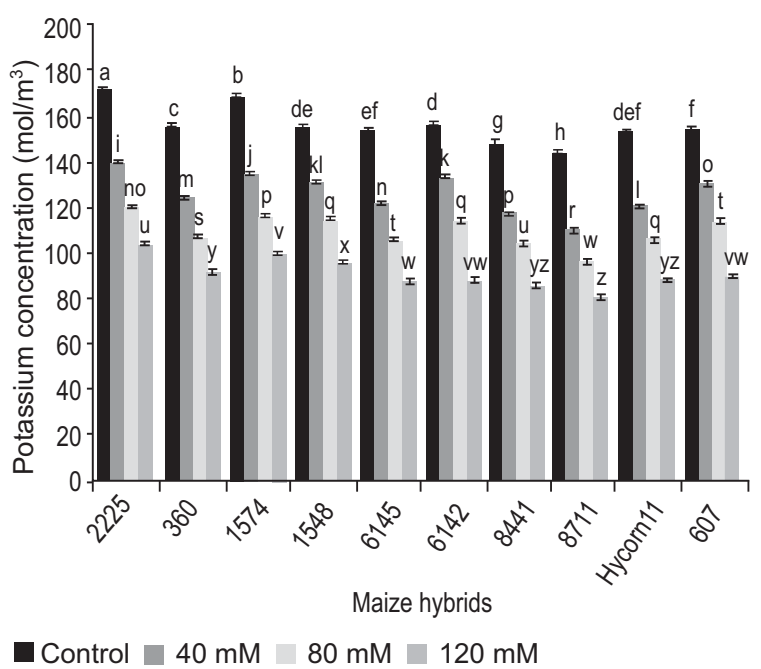

Fig. 4. Effect of salt stress on potassium concentration in leaf sap of ten maize hybrids. The bars in the graph show the mean values of five replicates and the error bars are the standard deviations.

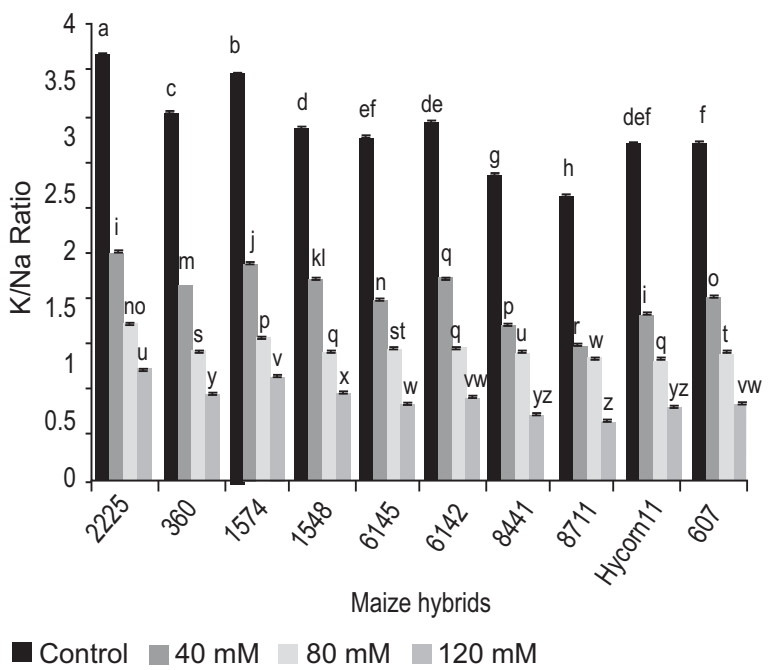

Fig. 6. Effect of salt stress on $\mathrm{K}^{+} / \mathrm{Na}^{+}$ concentration in leaf sap of ten maize hybrids. The bars in the graph show the mean values of five replicates and the error bars are the standard deviations.

main reason of RWC reduction under salinity might be ionic imbalance in plant cells affects that negatively affects availability of water in growth medium, disturb turgor potential of plant leaves and decrease in intercellular spaces ultimately lowers RWC (Abbasi et $a l ., 2014)$. Decrease in membrane stability index was noted with increasing $\mathrm{NaCl}$ concentration which 
deteriorates membrane integrity, causes increase in membrane permeability and reduces the succulence of leaves along with accumulation of ROS in cell membrane especially in salt sensitive plants (Kumari et al., 2017).

Under prolonged period of salt stress, accumulation of $\mathrm{Na}^{+}$in different plants parts results in stomatal closure and alteration in production of photosynthetic pigments such as chlorophyll which ultimately results in lowering chlorophyll contents (Negrao et al., 2017). These results were also supported by Abbasi et al. (2015) in maize.

Sodium $\left(\mathrm{Na}^{+}\right)$assist in regulating plant metabolism, while have drastic effects on plant morphology and physiology when surpasses from certain limit. Existence of $\mathrm{Na}^{+}$transport channels in cell membrane allow its entry into cell and serve as a key factor in tolerance or sensitivity of maize hybrids. The concentration of sodium increased with increasing salt levels in growth medium due to higher sodium transport and proportioning with in plant results in alteration of physiological and metabolic processes (Abbasi et al., 2016).

Salinity also leads to nutritional imbalance, competitive uptake and transport within the plant (Zeng et al., 2009). Potassium retaining capacity of plant cell is a major factor to check salt tolerance. More Potassium retaining capability of maize hybrid 2225 along with better growth, RWC, MSI and chlorophyll contents relative to other maize hybrids are major factors for better salinity tolerance. The reason for inferior potassium uptake under salinity might be due to competitive uptake of $\mathrm{Na}^{+}$and $\mathrm{Cl}^{-}$with certain nutrients like $\mathrm{K}^{+}, \mathrm{Ca}^{2+}$ and $\mathrm{Mn}^{2+}$ (Saqib et al., 2012). Higher $\mathrm{K}^{+} / \mathrm{Na}^{+}$ratio is a key factor that helps the salt-tolerant genotypes to perform well under salinity by regulating enzymes activation, osmoregulation and regulating cell turgor pressure with enhanced photosynthetic activity (Abbasi et al., 2012). Similar results were reported in maize by Hassan et al. (2018). The salt sensitivity of maize hybrids 8711 and 8441 was also because of their inability in retaining high $\mathrm{K}^{+}$concentration in the cell sap that resulted in lower $\mathrm{K}^{+} / \mathrm{Na}^{+}$ratio.

\section{Conclusion}

Being situated in arid and semiarid region, the process of salinization and sodification remains in progress in Pakistan. Results of this study indicate that salt stress has deleterious effects on growth, physiological, photosynthetic and ionic attributes of all maize hybrids and root/shoot length, fresh and dry biomass, chlorophyll contents, RWC and MSI along with $\mathrm{K}^{+} / \mathrm{Na}^{+}$ratio can serve as key parameters for characterization of different genotypes against salt stress. Maize hybrid 2225 show high $\mathrm{K}^{+} / \mathrm{Na}^{+}$ratio along with better morpho-physiological attributes under high salt stress declared it salt tolerant relative to other nine maize hybrids. Our results can be a potential source for plant breeders and crop physiologists due to their genetic variability and responsiveness to salinity and provide a good starting material for breeding of resistant genotypes that are able to grow at saline soil to make possible the utilization of waste saline water.

\section{Acknowledgement}

Authors are highly thankful to the department of Soil Science, University College of Agriculture and Environmental Sciences, The Islamia University of Bahawalpur for provision of financial and research facilities for a part of doctoral study.

Conflict of Interest. The authors declare no conflict of interest.

\section{References}

Abbasi, G.H., Akhtar, J., Haq, M.A., Ahmad, N. 2012. Screening of maize hybrids for salt tolerance at seedling stage under hydroponic condition. Soil and Environment, 31: 83-90.

Abbasi, G.H., Akhtar, J., Haq, M.A., Ali, S., Chen, Z.H., Malik, W. 2014. Exogenous potassium differentially mitigates salt stress in tolerant and sensitive maize hybrids. Pakistan Journal of Botany, 46: 135-146.

Abbasi, G.H., Akhtar, J., Ahmad, R., Jamil, M., Haq, M.A., Ali, S., Ijaz, M. 2015. Potassium application mitigates salt stress differentially at different growth stages in tolerant and sensitive maize hybrids. Plant Growth Regulations, 76: 111-125.

Abbasi, G.H., Jamil, M., Haq, A., Ali, S., Ahmad, R., Malik, Z. 2016. Salt stress manifestation on plants, mechanism of salt tolerance and potassium role in alleviating it: a review. Žemdirbyste (Agriculture), 103: 229-238.

Abraha, B., Yohannes, G. 2013. The role of seed priming in improving seedling growth of maize (Zea mays L.) under salt stress at field conditions. Agricultural Sciences, 4: 666-672.

Ahanger, M.A., Akram, N.A., Ashraf, M., Alyemeni, M.N., Wijaya, L., Ahmad, P. 2017. Plant responses to environmental stresses from gene to biotechnology. AoB Plants, 9: 80-99.

Ayoughi, F., Marzegar, M., Sahari, M.A., Naghdibadi, H. 2011. Chemical compositions of essential oils 
of Artemisia dracunculus L. and endemic Matricaria chamomilla L. and an evaluation of their antioxidative effects. Journal of Agricultural Science and Technology, 13: 79-88.

Flowers, T.J., Colmer, T.D. 2015. Plant salt tolerance: adaptations in halophytes. Annals of Botany, 115: 327-331.

Gupta, B., Huang, B. 2014. Mechanism of salinity tolerance in plants: physiological, biochemical and molecular characterization. International Journal of Genomics, 3: 14-20.

Hoagland, D.R., Arnon, D.I. 1950. The water-culture method for growing plants without soil. California Agricultural Experiment Station Circular, 347: 132.

Hassan, N., Hasan, M.K., Shaddam, M.O., Islam, M.S., Barutçular, C., Sabagh, A.E. 2018. Responses of maize varieties to salt stress in relation to germination and seedling growth. International Letters of Natural Sciences, 69: 1-11.

Katerji, N., Campi, P., Mastrorilli, M. 2013. Productivity, evapo-transpiration and water use efficiency of corn and tomato crops simulated by AquaCrop under contrasting water stress conditions in the Mediterranean region. Agricultural Water Management, 130: 14-26.

Kaya, C., Ashraf, M., Sonmez, O., Tuna, A.L., Polat, T., Aydemir, S. 2015. Exogenous application of thiamin promotes growth and antioxidative defense system at initial phases of development in salt-stressed plants of two maize cultivars differing in salinity tolerance. Acta Physiologiae Plantarum, 37: 17-41.

Kumari, J., Udawat, P., Dubey, A.K., Haque, M.I., Rathore, M.S., Jha, B. 2017. Over-expression of SbSI-1, A nuclear protein from Salicornia brachiata confers drought and salt stress tolerance and maintains photosynthetic efficiency in transgenic tobacco. Frontiers in Plant Science, 13: 12-15.

Kusvuran, A. 2015. The effects of salt stress on the germination and antioxidative enzyme activity of Hungarian vetch (Vicia pannonica Crantz.) varieties. Legume Research International Journal, 38: 51-59.

Lazcano-Ferrat, I., Lovatt, C.J. 1999. Relationship between relative water content, nitrogen pools and growth of Phaseolus vulgaris L. and P. acutifolius A. Gray during water deficit. Crop Science, 39: 467-475.

Medici, L.O., Azevedo, R.A., Canellas, L.P., Machado, A.T., Pimentel, C. 2007. Stomatal conductance of maize under water and nitrogen deficits. Pesquisa Agropecuaria Brasileira, 42: 599-601.
Negrao, S., Schmockel, S.M., Tester, M. 2017. Evaluating physiological responses of plants to salinity stress. Annals of Botany, 119: 1-11.

Sairam, R.K., Saxena, D.C. 2000. Oxidative stress and antioxidants in wheat genotypes: possible mechanism of water stress tolerance. Journal of Agronomy and Crop Science, 184: 55-61.

Saqib, Z.A., Akhtar, J., Haq, M.A., Ahmad, I., Bakhat, H.F. 2012. Rationality of using various physiological and yield related traits in determining salt tolerance in wheat. African Journal of Biotechnology, 11: 3558-3568.

Scudiero, E., Skaggs, T.H., Corwin, D.L. 2016. Comparative regional-scale soil salinity assessment with near-ground apparent electrical conductivity and remote sensing canopy reflectance. Ecological Indicators, 70: 276-284.

Thapar, R., Srivastava, A.K., Bhargava, P., Mishra, Y., Rai, L.C. 2008. Impact of different abiotic stresses on growth, photosynthetic electron transport chain, nutrient uptake and enzyme activities of $\mathrm{Cu}$ acclimated Anabaena doliolum. Journal of Plant Physiology, 165: 306-316.

Wellburn, A.R. 1994. The spectral determination of chlorophylls a and $\mathrm{b}$, as well as total carotenoids, using various solvents with spectrophotometers of different resolution. Journal of Plant Physiology, 144: 307-313.

Wolf, B. 1982. A comprehensive system of leaf analyses and its use for diagnosing crop nutrient status. Communications in Soil Science and Plant Analysis, 13: 1035-1059.

Yasmeen, A., Basra, S.M.A., Farooq, M., Rehman, H., Hussain, N. 2013. Exogenous application of moringa leaf extract modulates the antioxidant enzyme system to improve wheat performance under saline conditions. Plant Growth Regulations, 69: 225-233.

Zeng, F.R., Qiu, B., Ali, S., Zhang, G.P. 2009. Genotypic differences in nutrient uptake and accumulation in rice under chromium stress. Journal of Plant Nutrition, 33: 518-528.

Zhang, P., Senge, M., Dai, Y. 2016. Effects of salinity stress on growth, yield, fruit quality and water use efficiency of tomato under hydroponic system. Reviews in Agricultural Science, 4: 46-55.

Zhu, M., Zhou, M., Shabala, L., Shabala, S. 2017. Physiological and molecular mechanisms mediating xylem $\mathrm{Na}+$ loading in barley in the context of salinity stress tolerance. Plant Cell \& Environment, 40: 1009-1020. 